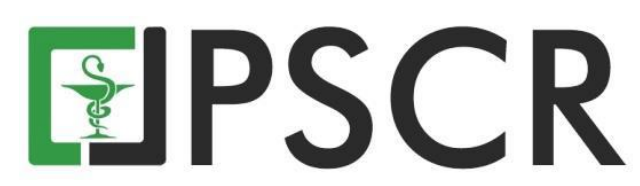

\title{
Rasionalitas Penggunanaan Obat Pada Pasien GERD Di Instalasi Rawat Inap Rumah Sakit Umum Anutapura Palu
}

\author{
Recky Patala $^{1 *}$, Joni Tandi ${ }^{1}$, Nurul Ulzmi ${ }^{1}$ dan Fahruddin ${ }^{2}$ \\ ${ }^{1}$ Program Studi S1 Farmasi, STIFA Pelita Mas, Jl. Wolter Monginsidi No.106A, Palu, Sulawesi Tengah, \\ Indonesia, 94111 \\ ${ }^{2}$ Rumah Sakit Umum Anutapura, Jl. Kangkung No.1, Palu, Sulawesi Tengah, Indonesia, 94111 \\ *email korespondensi: Reckyfarmasi@gmail.com
}

Received 16 June 2019, Accepted 29 September 2020, Published 15 March 2021

\begin{abstract}
Abstrak: Gastroesophageal Refluks Disease (GERD) merupakan suatu keadaan patologis dimana cairan lambung dengan berbagai kandungannya mengalami refluks ke dalam esophagus. Penyakit ini terjadi akibat lower esophageal sphincter yang berada diantara esophagus dan lambung tidak berfungsi dengan baik. Penelitian ini bertujuan untuk mengetahui rasionalitas penggunaan obat yang meliputi tepat indikasi, tepat obat dan tepat dosis. Subyek pada penelitian ini adalah pasien GERD yang memenuhi kriteria inklusi dan ditentukan berdasarkan rumus Slovin. metode penelitian yang digunakan observasional dengan pendekatan cross sectional dengan teknik purposive sampling dimana penelitian ini mendeksripsikan dan mengkaji rasionalitas penggunaan obat pada pasien GERD di RSU Anutapura Palu periode Oktober 2019-Januari 2020. Hasil penelitian menunjukkan penggunaan obat pada pasien GERD di Instalasi Rawat Inap RSU Anutapura Palu sudah rasional dengan persentase penggunaan obat berdasarkan tepat indikasi sebesar 96,97\%, tepat obat 96, $97 \%$ dan tepat dosis sebesar $100 \%$.
\end{abstract}

Kata Kunci: Rasionalitas; GERD; Penggunaan obat; Rekam Medik; Rumah Sakit Umum Anutapura

Abstract: Rationality Drug Use of GERD patients in Anutapura Hospital Palu. Gastroesophageal Reflux Disease (GERD) is a pathologic condition in which gastric fluid with various contents reflux into the esophagus. This disease occurs due to the lower esophageal sphincter that is between the esophagus and stomach does not function properly. The study aimed to examine drug use wich includes precise indications, precise drugs, a precise dose. The subject in this research was GERD patients who met the criteria of inclusion and was determined by the slovin formula. The research method was observational approaches with a sectional sampling technique that enhances and studies the prevalence of pharmacology. The result showed that the use of drugs of GERD patients in Anutapura General Hospital Palu has been rational with percentage of based on precise indications was $96,97 \%$, based on the appropriate remedy was $96,97 \%$, and the percentage of drug use based on the exact dose was $100 \%$

Keywords: Rationality; GERD; Drug use, Medical Record; Anutapura Hospital

\section{Pendahuluan}

Gastroesophageal Refluks Disease (GERD) merupakan suatu kondisi patologis penyakit yang diakibatkan oleh adanya refluks kandungan isi lambung menuju esophagus, yang disertai dengan adanya gejala yang timbul di esophagus maupun di ekstra-esophagus. Refuks 
kandungan isi lambung menuju ke esophagus dapat menyebabkan komplikasi yang berat seperti esophagitis refluks yang merupakan keadaan terbanyak dari penyakit GERD (Sudoyo, Setiyohadi, Alwi, Simadibrata, \& Setiati, 2009). Kembalinya isi lambung ke esofagus dapat berakibat terhadap gangguan secara fungsional dan gangguan struktural tanpa adanya kelainan lain dapat mempengaruhi penutupan sfingter esofagus bawah (SEB) ( Puspita, Putri, Rahardja, Utari, \& Syam, 2017). GERD dapat disebabkan oleh gaya hidup seperti merokok, mengkonsumsi alkohol, obesitas, makan terlalu banyak, kopi, stress, serta berbaring setelah makan makanan pedas (Heidelbaugh, Rew, \& Harrison, 2013).

Beberapa faktor resiko terjadinya GERD antara lain obesitas, usia lebih dari 40 tahun, stress, kehamilan, merokok, diabetes, skleroderma. Beberapa obat dan suplemen diet pun dapat memperparah gejala GERD, seperti obat-obatan yang dapat mengganggu kerja otot sfingter esophagus bagian bawah seperti antidepressan, calcium channel blockers dan narkotika. Termasuk juga penggunaan rutin beberapa jenis nonsteroidal anti-inflammatory drugs (NSAIDs) dan antibiotika (Tarigan \& Pratomo, 2019). Gejala klinik yang khas dari GERD adalah nyeri/rasa tidak enak di epigastrium yang ditandai dengan seperti rasa terbakar (heartburn), kadang-kadang bercampur dengan gejala disfagia (kesulitan menelan makanan), serta rasa mual dan pahit di lidah. Pemeriksaan endoskopik tidak berkorelasi dengan derajat berat atau ringannya keluhan heartburn (Ndraha, Oktavius, Sumampouw, Juli, \& Marcel, 2016).

Berdasarkan data pada tahun 2017 di Rumah Sakit Umum (RSU) Anutapura Palu pada instalasi rawat inap diperoleh jumlah pasien GERD sebanyak 528 pasien dengan jenis kelamin laki-laki 198 orang dan perempuan 330 orang. Pasien terbanyak antara umur 25-44 tahun sebanyak 148 orang, sedangkan pada tahun 2018 diperoleh jumlah pasien GERD sebanyak 1.258 pasien dengan jenis kelamin laki-laki sebanyak 439 orang, perempuan 819 orang. Pasien terbanyak antara umur 24-44 tahun sebanyak 429 orang. World Health Organization (WHO) memperkirakan bahwa lebih dari separuh dari seluruh obat di dunia yang diresepkan, diberikan dan dijual dengan cara yang tidak tepat (WHO, 2010). Peresepan obat dengan indikasi yang tidak jelas, penentuan dosis, cara dan lama pemberian yang tidak tepat serta harga obat yang cukup mahal merupakan contoh dari penggunaan obat yang tidak rasional. Hal ini dapat menimbulkan adanya dampak negatif yang diterima oleh pasien (Kemenkes RI, 2011). Pada penelitian sebelumnya yang telah dilakukan oleh Friyanto \& Lestari (2019) dengan menggunakan rancangan penelitian analis kuantitatif untuk mengetahui angka kejadian, kerasionalan penggunaan obat dan faktor hubungan penyakit GERD, menyebutkan bahwa angka kejadian GERD di RSUD Karawang adalah 68 pasien, pada pasien perempuan lebih tinggi sebesar 51,5\% (35 pasien), hasil rata-rata rasionalitas penggunaan obat pada pasien 
GERD yaitu tepat indikasi sebesar 80,4\%, tepat obat sebesar 59,3\%, tepat pasien sebesar $89,7 \%$ dan tepat dosis sebesar 64\%. Hasil tersebut menunjukan bahwa terapi pengobatan pasien GERD di RSUD Karawang sudah rasioanal. Faktor jenis kelamin dalam penelitian ini berpengaruh terhadap tanda dan gejala pasien GERD, sedangkan untuk Umur dan penyakit penyerta tidak berpengaruh atau bukan faktor resiko terhadap tanda dan gejala pasien GERD.

Berdasarkan uraian dari latar belakang tersebut yang menunjukan bahwa studi tentang rasionalitas penggunanaan obat pada pasien GERD di instalasi rawat inap Rumah Sakit Umum Anutapura Palu secara berkala penting untuk dilakukan. Belum banyak studi di Indonesia yang membahas tentang penggunanaan obat pada pasien GERD berdasarkan tingkat rasionalitasnya. Penelitian ini bertujuan untuk mengetahui rasionalitas penggunaan obat yang meliputi tepat indikasi, tepat obat dan tepat dosis.

\section{Metode Penelitian}

\subsection{Populasi dan Subyek penelitian}

Populasi dalam penelitian ini adalah semua pasien dengan diagnosa GERD baik dengan atau tanpa komplikasi yang dari diagnosa utamanya atau yang muncul selama masa perawatan di ruang perawatan Cendrawasih Bawah, Rajawali Bawah dan Rajawali Atas di RSU Anutapura Palu periode Oktober 2019-Januari 2020. Subyek penelitian adalah pasien GERD yang memenuhi kriteria inklusi. Adapun kriteria inklusi yaitu 1) pasien yang dengan diagnosa sindroma GERD yang dirawat di ruang rawat inap, 2) pasien dengan penyakit tertentu dengan tanda dan gejala ikutan GERD yang di rawat di ruang rawat inap dan 3) pasien dengan lama perawatan $\geq 3$ hari di rawat di ruang rawat inap. Disamping itu, kriteria eksklusi meliputi 1) pasien yang dirawat kurang dari 1 hari, baik yang izinkan pulang, pulang paksa ataupun yang meninggal dunia, 2) pasien yang hanya mendapatkan satu jenis obat dan 3) pasien dengan data hilang.

\subsection{Prosedur Penelitian}

Jenis penelitian yang digunakan dalam penelitian ini merupakan penelitian non eksperimental observasional yang dilakukan dengan pendekatan cross sectional menggunakan teknik purposive sampling secara prospektif dan hasil penelitian disajikan secara deskriptif. Pengumpulan data dilakukan dengan cara menggunakan data sekunder dengan mengambil catatan dari rekam medik pasien yang sedang dirawat di ruang rawat inap RSU Anutapura Palu. Data dikumpulkan pada Lembaran Pengumpul Data (LPD), dilakukan identifikasi masalah terkait obat dengan berfokus pada masalah kerasionalan terapi. Data yang diperoleh dari rekam medis dievaluasi kerasionalannya menggunakan Informasi Spesialite Obat (ISO), Informatorium Obat Nasional Indonesia (IONI) dan Medscape 


\section{Hasil dan Pembahasan}

\subsection{Karakteristik Pasien}

Data distribusi pasien menunjukkan bahwa data pasien berdasarkan jenis kelamin perempuan sebanyak 37 orang $(51,39 \%)$ dan laki-laki sebanyak 35 orang $(48,61 \%)$ (Tabel 1). Hal ini tidak menunjukkan adanya perbedaan yang signifikan antara jumlah pasien wanita dan pasien pria sehingga dapat disimpulkan jenis kelamin bukan merupakan faktor resiko utama pada GERD. Untuk data usia yang paling tinggi yaitu 44-64 tahun sebanyak 24 pasien $(33,33 \%)$, hal ini disebabkan karena perubahan fisiologis esophagus seiring dengan bertambahnya usia berupa menurunnya produksi saliva bikarbonat sehingga meningkatkan paparan refluks asam di esophagus akibat lambatnya bersihan asam, sehingga akan menurunkan panjang relaksasi LES dan menyebabkan motilitas esophagus dengan meningkatnya proporsi peristaltis yang abnormal dan lambatnya bersihan asam refluks pada esophagus (Syam, Hapsari \& Makmun, 2016). Karina, Fajar \& Ratna, (2015) dalam penelitiannya menyebutkan bahwa angka kejadian GERD yang tinggi terjadi pada usia produktif yaitu di atas 40 tahun, karena berbagai kesibukan pekerjaan dan kegiatan lainnya yang sangat berpotensi menimbulkan pola hidup tidak sehat dan stress yang dapat meningkatkan resiko penyakit GERD. Untuk data jumlah pasien yang didiagnosa penyakit GERD sebesar 35 pasien $(48,6 \%)$ sedangkan dengan penyakit penyerta menunjukkan jumlah pasien yaitu sebanyak $37(51,4 \%)$.

Tabel 1. Distribusi pasien GERD berdasarkan jenis kelamin, usia dan penyakit penyerta di RSU Anutapura Palu periode Oktober 2019-Januari 2020.

\begin{tabular}{clcc}
\hline No & \multicolumn{1}{c}{ Karakteristik Pasien } & Jumlah pasien $(\mathbf{N}=\mathbf{7 2})$ & Prsentase $\mathbf{( \% )}$ \\
\hline 1. & Jenis Kelamin & 35 & \\
& Laki-laki & 37 & 48,61 \\
& Perempuan & & 51,39 \\
\hline 2. & Usia & 20 & 27,78 \\
15-24 & 16 & 22,22 \\
$25-44$ & 24 & 33,33 \\
$44-64$ & 12 & 16,67 \\
$>65$ & & \\
3. Penyakit Penyerta & 1 & 1,4 \\
General weakness & 1 & 1,4 \\
Hipertiroid & 1 & 1,4 \\
Gangguan ginjal & 2 & 2,8 \\
Anxietas disorders & 3 & 4,2 \\
Infeksi Saluran Kemih (ISK) & 3 & 4,2 \\
Febris & 4 & 5,6 \\
Neuropati & 5 & 6,9 \\
Infeksi Saluran Pernafasan Akut & 6 & 8,3 \\
(ISPA) & 8 & 11,1 \\
Gangguan Saluran Pencernaan & & \\
Kardiovaskuler & & \\
\hline
\end{tabular}


Mengkonsumsi makanan pedas secara berlebihan akan merangsang sistem pencernaan, terutama lambung dan usus untuk berkontraksi sehingga mengakibatkan rasa panas dan nyeri diulu hati yang disertai dengan mual dan muntah yang menyebabkan semakin berkurangnya nafsu makan (Merita, Wilpi \& Irawati, 2016). Pasien GERD dengan riwayat penyakit yang beresiko menjadi penyebab GERD, resiko tersebut disebabkan dari faktor resiko penyakit yang hampir sama dengan penyakit GERD, dan penyakit penyerta dengan penggunaan obat terapi seperti obat asma dan AINS dan obat-obatan lain yang dapat menurunkan tekanan tonus LES (Saputera \& Budianto, 2017). Obat anti inflamasi non steroid (OAINS) dapat merusak mukosa lambung melalui 2 mekanisme, yaitu kerusakan mukosa yang terjadi akibat penurunan produksi prostaglandin dan kerusakan secara topikal yang terjadi karena AINS bersifat lipofilik dan asam (Muhi \& Utami, 2016).

\subsection{Karakteristik Pengobatan}

Hasil analisis distribusi pengobatan berdasarkan golongan obat menunjukkan data golongan obat GERD yang paling sering digunakan berdasarkan jumlah peresepan yang diberikan yaitu obat omeprazol golongan Pompa Proton Inhibitor (PPI) sebanyak 66 kali $(47,48 \%)$ (Tabel 2). Hal ini disebabkan karena obat golongan PPI memberikan efek penekanan asam lambung yang lebih besar dan efektif dibandingkan dengan obat anti refluks lainnya. Obat golongan PPI dapat menghambat pompa proton secara ireversible dalam sel pariental sehngga mengurangi sekresi asam lambung. Obat-obat golongan PPI dapat menyembuhkan esophagitis lebih cepat serta lebih efektif dalam menjaga $\mathrm{pH}$ asam lambung di atas empat untuk jangka waktu yang lama (MacFarlane, 2018). Berdasarkan standar pengobatan menurut (Syam, Aulia, Renaldi, Simadibrata, Abdullah, \& Tedjasaputra, 2013) dalam Konsensus Nasional, obat golongan PPI merupakan terapi lini pertama yang digunakan pada pasien GERD, dimana terapi empirik PPI diberikan selama 4 minggu dan dievaluasi dalam 2-4 minggu. Omeprazol bekerja dengan cara memblok aktivasi $\mathrm{H}+, \mathrm{K}+$-ATPase melalui pembentukan ikatan sulfonamid dengan residu sistein pada enzim tersebut. $\mathrm{H}+\mathrm{K}+\mathrm{ATP}$ ase adalah enzim dalam sel parietal lambung yang dikenal juga sebagai pompa proton yang merupakan jalur akhir sekresi asam pada lambung (Aguilera, Carlos \& Agustin, 2016). Omeprazol memiliki waktu puncak plasma 30 menit sampai 3,5 jam dan onset 1 jam, sedangkan obat pantoprazol memiliki waktu puncak plasma 2,8 jam dengan onset 24 jam dan durasi selama 7 hari, dan obat lansoprazol memiliki waktu puncak plasma 1,7 jam dan onset 1-3 jam dengan durasi > 24 jam. Sehingga ketersediaan hayati obat pantoprazol dan lanzoprazol lebih banyak dibandingkan omeprazol namun omeprazol lebih cepat mencapai kadar puncak plasma sehingga lebih cepat memberikan efek. Terbanyak kedua yang sering digunakan yaitu obat Domperidon sebanyak 42 kali (30,21\%), hal ini disebabkan karena obat golongan prokinetik merupakan salah satu tatalaksana 
Tabel 2. Distribusi pengobatan berdasarkan golongan obat pada pasien Gastroesophageal Refluks Disease (GERD) di RSU Anutapura Palu periode Oktober 2019-Januari 2020.

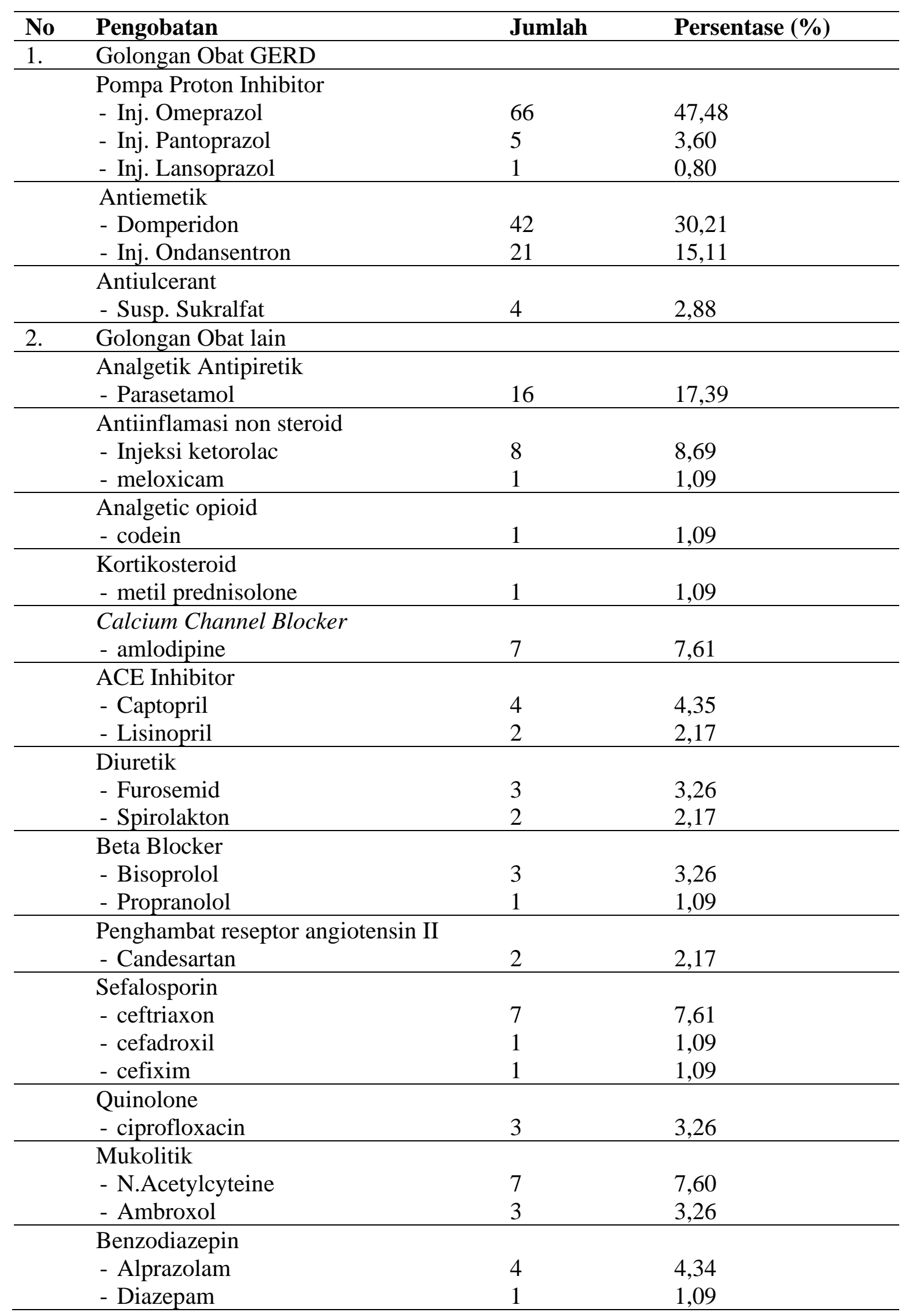


medikamentosa dari GERD, antagonis reseptor gamma amino butyric acid B (GABA-B) merupakan obat golongan prokinetik yang dapat menghambat relaksasi transien sfingter bawah esophagus, beberapa penelitian menunjukkan bahwa obat golongan prokinetik akan mengurangi frekuensi relaksi sfingter esophagus, paparan asam lambung terhadap esophagus serta mempercepat pengosongan lambung yang merupakan gejala-gejala refluks (Putra, Jurnalis \& Sayoeti, 2019). Obat domperidon digunakan pada refluks esophagitis untuk mencegah aliran balik asam lambung ketenggorokan, begitu pula pada mual dan muntah dengan berbagai sebab. Berbeda dengan metoklopramid, obat domperidon tidak memasuki cairan cerebro spinal (CCS) sehingga tidak berefek sedatif (Nuryati, 2017).

Tabel 2. Distribusi pengobatan berdasarkan golongan obat pada pasien Gastroesophageal Refluks Disease (GERD) di RSU Anutapura Palu periode Oktober 2019-Januari 2020 (lanjutan).

\begin{tabular}{|c|c|c|c|}
\hline No & Pengobatan & Jumlah & Persentase (\%) \\
\hline & $\begin{array}{l}\text { Glikosida Jantung } \\
\text { - Digoxin }\end{array}$ & 2 & 2,17 \\
\hline & $\begin{array}{l}\text { Nitrat } \\
\text { - ISDN }\end{array}$ & 1 & 1,09 \\
\hline & $\begin{array}{l}\text { Antiplatelet } \\
\text { - Clopidogrel }\end{array}$ & 1 & 1,09 \\
\hline & $\begin{array}{l}\text { Antithyroid } \\
\text { - PTU }\end{array}$ & 1 & 1,09 \\
\hline & $\begin{array}{l}\text { Antivertigo } \\
\text { - Vastigo }\end{array}$ & 2 & 2,17 \\
\hline & $\begin{array}{l}\text { Antihistamin H1 } \\
\text { - Cetrizin }\end{array}$ & 2 & 2,17 \\
\hline & $\begin{array}{l}\text { Antifungi } \\
\text { - Nystatin }\end{array}$ & 2 & 2,17 \\
\hline & $\begin{array}{l}\text { Vitamin saraf } \\
\text { - B Complex }\end{array}$ & 1 & 1,08 \\
\hline & $\begin{array}{l}\text { Hemostatic } \\
\text { - Kalnex }\end{array}$ & 1 & 1,08 \\
\hline
\end{tabular}

Kombinasi obat golongan PPI dan prokinetik diketahui dapat meningkatkan efek dari obat golongan PPI dimana obat golongan PPI tidak stabil pada $\mathrm{pH}$ rendah sehingga obat prokinetik yang berfungsi mempercepat pengosongan lambung dapat memberikan efek yang menguntungkan untuk obat golongan PPI (Ndraha, Oktavius, Sumampouw, Juli, \& Marcel, 2016).

Golongan analgetik antipiretik dapat meringankan keluhan berupa rasa nyeri yang biasa dialami oleh pasien GERD. Diketahui bahwa beberapa faktor resiko penyebab hipertensi adalah stress dan obesitas yang merupakan faktor resiko utama penyebab GERD, pada pasien yang mengalami obesitas lemak dapat dapat meningkatkan tekanan darah (Korneliani \& Dida, 2012). Berdasarkan hasil penelitian Tong, Feng, Xing, \& Li (2018) menunjukkan bahwa terapi obat 
asam dapat mengurangi tekanan darah sistolik dan diastolik pasien dengan hipertensi esensial dan GERD. Obat golongan antibiotik biasanya diberikan pada pasien GERD yang disebabkan oleh infeksi bakteri H. pylori, atau dikarenakan terjadinya infeksi akibat dari penyakit penyerta, sedangkan obat golongan mucolitik/ekspectoran digunakan untuk menanggani keadaan pada bronkial akut dan kronik, dan paru dengan mukus yang tebal dan sebagai sekretolitik yang dapat mempermudah pengeluaran sekret yang kental dan lengket didalam saluran pernafasan (ISO, 2015). Nurrokhmawati, Teti \& Ratna (2012) menyatakan bahwa keluhan refluks terbanyak yang ditemukan pada semua subjek penelitian adalah berdehem dan adanya dahak. Hal ini disebabkan karena adanya sekret di belakang hidung pada semua pasien yang berhubungan dengan faring dan nasofaring akibat terpaparnya refluks asam yang dapat meningkatkan sekresi nasal. Jika mekanisme pertahanan laring menghilang, akan terjadi disfungsi silia yang akan menyebabakan penumpukan mukus menghasilkan sekret di belakang hidung serta menginduksi dehem. Akumulasi sekret dan zat asam akan menyebabkan iritasi pada saraf sensori laring yang sangat sensitif sehingga akan menimbulkan gejala batuk dan tersedak. Dalam tatalaksana untuk GERD pengobatan dilakukan selama 2-4 minggu dengan terapi pemberian PPI dan setelah perawatan, pasien diberikan terapi dengan dosis pemeliharaan 4-8 minggu untuk mencegah kekambuhan gejala (Marchetti \& Livia, 2009).

Lama perawatan merupakan salah satu faktor yang dapat digunakan untuk mengukur tingkat efektivitas penggunaan obat (Farida, Trisna, \& Nur, 2017) (Farida, Putri, Hanafi, \& Herdianti, 2020). Berdasarkan hasil Tabel 3 menunjukkan data jumlah pasien penyakit GERD yang menjalani perawatan di instalasi rawat inap RSU Anutapura Palu berdasarkan lama perawatan yang paling tinggi adalah 1-7 hari sebanyak 65 pasien (90,28\%). Hal ini menunjukkan bahwa terapi pengobatan GERD yang diberikan kepada pasien sudah sesuai dengan gejala dan hasil diagnosa yang dialami pasien sehingga pasien memperoleh dampak semakin cepatnya gejala atau keluhan yang membaik dan pasien tidak memerlukan waktu perawatan yang lama di rumah sakit. Pratiwi \& Rano (2014) menyebutkan bahwa penggunaan obat yang rasional adalah penggunaan obat yang disesuaikan dengan kebutuhan klinis pasien, baik dalam jumlah maupun menurunkan LOS (Length of Stay) pasien rawat inap disertai dengan biaya yang rendah.

Tabel 3. Distribusi berdasarkan lama rawat inap pasien penyakit GERD yang menjalani perawatan di instalasi rawat inap RSU Anutapura Palu.

\begin{tabular}{ccc}
\hline Lama rawat inap & Jumlah pasien & Persentase $(\boldsymbol{\%})$ \\
\hline 1-7 hari & 65 & 90,28 \\
8-14 hari & 7 & 9,72 \\
\hline Total & 72 & 100 \\
\hline
\end{tabular}




\subsection{Rasionalitas Penggunaan Obat GERD}

\subsubsection{Tepat Indikasi}

Berdasarkan hasil pada Tabel 4 dari data jumlah pasien penyakit GERD yang menjalani perawatan di instalasi rawat inap RSU Anutapura Palu diperoleh tepat indikasi sebanyak 224 kasus sebesar 96,97\% dan yang tidak tepat sebanyak 7 kasus sebesar 3,03\% yaitu N.Acetylcyteine (2), Ceftriaxone (2), Digoxin, Propiltiourasil, dan Nystatin. N.Acetylcyteine sebagai mukolitik pada brokial akut dan kronik serta paru dengan mukus yang tebal, tidak sesuai diberikan pada pasien dengan diagnosa Hipertiroid, Febris dan GERD, nyeri dan GERD. Ceftriaxone digunakan untuk infeksi yang disebabkan oleh bakteri patogen tidak sesuai diberikan kepada pasien tanpa diagnosis infeksi, untuk obat Propiltiourasil dan Digoxin tidak sesuai diberikan pada pasien dengan diagnosa GERD, sedangkan untuk obat Nystatin tidak sesuai diberikan pada pasien dengan diagnosa gangguan saluran cerna yaitu colic abdomen dan GERD (ISO, 2015; PIONAS, 2014).

Penulisan resep tanpa indikasi yang jelas atau indikasi yang seharusnya dapat menyebabkan pemberian obat yang tidak sesuai dengan gejala dan diagnosa dapat menyebabkan berbagai dampak negatif terhadap pasien sehingga tepat indikasi merupakan salah syarat dalam rasionalitas dalam penggunaan obat (Pratiwi \& Rano, 2014).

Tabel 4. Distribusi tepat indikasi pada pasien GERD yang menjalani perawatan di instalasi rawat inap RSU Anutapura Palu.

\begin{tabular}{ccc}
\hline Tepat indikasi & Jumlah obat & Persentase (\%) \\
\hline Tepat & 224 & 96,97 \\
Tidak tepat & 7 & 3,03 \\
\hline Total & 231 & 100 \\
\hline
\end{tabular}

\subsubsection{Tepat Obat}

Berdasarkan hasil pada Tabel 5 diperoleh data tepat obat sebanyak 224 (96,97\%) dan yang tidak tepat sebanyak $7(3,03 \%)$. Tidak tepat obat ini terkait dengan tidak tepat indikasi. Obat diberikan kepada pasien tanpa adanya gejala yang sesuai. Hasil tersebut memnujukkan bahwa pemberian obat yang tidak memiliki efek terapi sesuai dengan diagnosis penyakit, dimana tepat obat adalah obat yang digunakan efektif, artinya dapat memberikan perbaikan keadaan pasien, serta obat yang diberikan harus memberikan manfaat yang besar dibanding resiko atau efek samping yang ditimbulkan dan sesuai dengan standar terapi yang digunakan sebagai acuan (Kemenkes, 2011) 
Tabel 5. Distribusi tepat obat pada pasien GERD yang menjalani perawatan di instalasi rawat inap RSU Anutapura Palu.

\begin{tabular}{ccc}
\hline Tepat obat & Jumlah obat & Persentase (\%) \\
\hline Tepat & 224 & 96,97 \\
Tidak tepat & 7 & 3,03 \\
\hline Total & 231 & 100 \\
\hline
\end{tabular}

\subsubsection{Tepat Dosis}

Berdasarkan hasil pada Tabel 6 menunjukkan jumlah peresepan dilihat dari tepat pemberian dosis yaitu sebesar 231 (100\%). Pada kasus ini pemberian obat omeprazol yang diberikan kepada pasien adalah $40 \mathrm{mg}$ setiap 24 jam hal ini sesuai dengan dosis yang dianjurkan untuk penyakit GERD yaitu 20-40 mg/24 jam (Tjay \& Kirana, 2013) selama 4 minggu yang diikuti 4-8 minggu berikutnya jika tidak sembuh akan ditingkatkan menjadi $40 \mathrm{mg}$ setelah 8 minggu pada pasien yang tidak bisa disembuhkan dengan terapi lain. Dan dosis pemeliharan 20 mg (PIONAS, 2014). Untuk sediaan injeksi intravena omeprazol yang diindikasikan untuk kasus berat Gastroesophageal Refluks Disease, tukak duodenum dan tukak lambung diberikan dosis lazim 40 mg sekali sehari selama 8 minggu (ISO, 2015).

Tabel 6. Distribusi tepat dosis pada pasien GERD yang menjalani perawatan di instalasi rawat inap RSU Anutapura Palu.

\begin{tabular}{ccc}
\hline Tepat dosis & Jumlah kasus & Persentase (\%) \\
\hline Tepat & 231 & 100 \\
Tidak tepat & 0 & 0 \\
\hline Total & 231 & 100 \\
\hline
\end{tabular}

\section{Kesimpulan}

Berdasarkan hasil penelitian yang telah dilakukan dapat disimpulkan bahwa penggunaan obat pada pasien penyakit GERD di instalasi rawat inap RSU Anutapura Palu sudah rasional dengan kriteria yang diperoleh yaitu tepat indikasi sebesar 96,97\%, tepat obat sebesar 96,97\% dan tepat pemberian dosis yaitu sebesar $100 \%$.

\section{Ucapan Terima Kasih}

Kepada seluruh tenaga medis di Instalasi Rawat Inap Rumah Sakit Umum Anutapura Palu atas bantuan dan kerjasamanya yang baik.

\section{Deklarasi konflik kepentingan}

Semua author menyatakan bahwa tidak ada konflik kepentingan dalam penulisan naskah ini.

\section{Daftar Pustaka}

Aguilera, L.C., Carlos, M.D.A.D P., \& Agustin, A. N. (2016). Practical Consideration In The Management OF Proton-pump Inhibitors. Journal REV ESP ENFERM DIG, 108(2), 145 153. 
Farida, Y., Putri, V. W., Hanafi, M., \& Herdianti, N. S. (2020). Profil Pasien dan Penggunaan Antibiotik pada Kasus Community-Acquired Pneumonia Rawat Inap di Rumah Sakit Akademik Wilayah Sukoharjo. JPSCR: Journal of Pharmaceutical Science and Clinical Research, 5(2), 151-164.

Farida, Y., Trisna, A., \& Nur, D. (2017). Study of Antibiotik Use on Pneumonia Patient in Surakarta Referral Hospital. Journal of Pharmaceutical Science and Clinical Research, 02(1), 44-52.

Friyanto, D., \& Lestari, S. (2019). Analisis Penggunaan Obat Gastroesophageal Reflux Disease (GERD) Pada Pasien Rawat Jalan Di Rumah Sakit Umum Daerah Karawang. Pharma Xplore : Jurnal Sains dan Ilmu Farmasi, 4(1), 240-247.

Heidelbaugh, J. J., Rew, K.T., \& Harrison, R. V. (2013). Gastroesophageal Reflux Disease (GERD). In UMHS GERD Guideline.

Informatorium Obat Nasional Indonesia (PIONAS) (2015), Badan Pengawas Obat dan Makanan Republik Indonesia: Jakarta.

Informasi Spesialite Obat Indonesia (ISO) Volume 49. 2015. Jakarta: PT. ISFI.

Karina, R., Fajar A.Y., \& Ratna, D. I. A. (2015). Karakteristik Penderita Gatroesophageal Refluks Disease (GERD) Berdasarkan Usia, Jenis Kelamin, Dan Keluhan Utama di Poli Penyakit Dalam Rumah Sakit Al Islam Bandung Tahun 2015. Prosiding Pendidikan Dokter, 2(2), 224-230.

Kemenkes RI. (2011). Modul Penggunaan Obat Rasional. Kemenkes RI, 1, 3-8.

Korneliani, K. \& Dida, M. (2012). Obesitas dan Stress Dengan Keajadian Hipertensi. Jurnal kesehatan masyarakat, 7(2), 117-121.

MacFarlane, B. (2018). Management of gastroesophageal reflux disease in adults: a pharmacistrsquo;s perspective. Integrated Pharmacy Research and Practice, 7, 41-52.

Marchetti,N. \& Livia C. (2009). Pharmacist Guidelines For The Management Of GERD in Adult Opportunities For Practic Change Under B.C.'1s Protocol For Medication Management. Pharmacy Practice disease Gastroenterology Research and Practice, 50(16), 119-126.

Merita, Wilpi I.S \& Irawati S. (2016). Hubungan Tingkat Stress Dan Pola Konsumsi Dengan Kejadian Gastritis Di Puskesmas Pakuan Baru Jambi. Jurnal Akademika Baiturrahim, 5(1), 51-58.

Muhi, A. F., \& Utami, N. (2016). Hubungan Konsumsi OAINS Terhadap Gastritis. Majority, 5(5), 18-21.

Ndraha, S., Oktavius, D., Sumampouw, J. L., Juli, N. N., \& Marcel, R. (2016). Artikel Penelitian Faktor-Faktor yang Berhubungan dengan Keberhasilan Terapi GERD Factors Associated with The Success of GERD Therapy. Journal Kedokteran Meditek, 22(60), $7-13$.

Nuryati. (2017). Farmakologi. Jakarta: Kementrian Kesehatan Republik Indonesia, 151-152.

Nurrokhmawati, Y., Teti M., \& Ratna. A. A. (2012). Efektivitas Pemberian Antibiotik Disertai Lansoprazol Pada Refluks Laring Faring Dengan Infeksi Helicobacter pyolori. MBK, 44(4), 224-232.

PIONAS, 2014. Informatorium Obat Nasional Indonesia (IONI). Jakarta, Badan Pengawas Obat dan Makanan.

Pratiwi, A. A., \& Rano, K.S. (2014). Analisis Peresepan Obat Anak Usia 2-5 Tahun di Kota Bandung Tahun 2012. Jurnal Farmasi Klinik Indonesia, 3(1), 18-23.

Putra, H., Jurnalis, Y. D., \& Sayoeti, Y. (2019). Tatalaksana Medikamentosa pada Penyakit Saluran Cerna. Jurnal Kesehatan Andalas, 8(2), 407-418.

Puspita, F. C., Putri, L. A., Rahardja, C., Utari, A. P., dan Syam, A. F. (2017). Prevalence of Gastroesophageal Reflux Disease and Its Risk Factors In Rural Area. The Indonesian Journal of Gastroenterology, Hepatology, and Digestive Endoscopy, 18(1), 9-14.

Saputera, M. D., \& Budianto, W. (2017).. Diagnosis dan tatalaksana gastroesophageal reflux disease (GERD) di pusat pelayanan kesehatan primer. Journal Continuing Medical 
Education, 44(5), 329-332.

Sudoyo, W., Setiyohadi, B., Alwi, I., Simadibrata, K.., \& Setiati, S. (2009). Buku Ajar Ilmu Penyakit Dalam Jilid I (V). Jakarta: Interna Publishing.

Syam, A. F., Hapsari, P. F. C., \& Makmun, D. (2016). The Prevalence and Risk Factor of GERD Among Indonesian Medical Doctors. The Indonesian Journal of Gastroenterology, Hepatology, and Digestive Endoscopy, 20(2), 35-40.

Syam A. F., Aulia, C., Renaldi, K., Simadibrata, M., Abdullah, M., \& Tedjasaputra, T. R., (2013). Revisi Konsensus Nasional Penatalaksanaan Penyakit Refluks Gastroesofageal (Gastroesophageal Reflux Disease/ GERD) Di Indonesia.

Tarigan, R.C., \& Pratomo, B. (2019). Analisis Faktor Risiko Gastroesofageal Refluks di RSUD Saiful Anwar Malang. Jurnal Penyakit Dalam Indonesia, 6(2), 78-81.

Tjay, T. H., \& Kirana, R. (2013). Obat-Obat Penting. Edisi Ke-V. Jakarta: PT. Gramedia.

Tong. L.Z., Feng J., Xing. W.H. \& Li W. (2018). Derule of Gastroesophageal Refluks in Provoking High Blood Pressure Episodes in Patients With Hypertention. Journal Clin Gastroentero, 52(8), 685-891.

WHO., 2010. The World Health Report 2010. http://www.who.int./whr/2010/en/index.html Akses 13 Desember 2019.

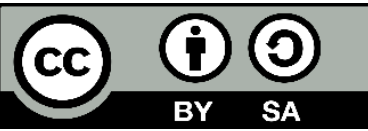

C 2021 by the authors. Submitted for possible open access publication under the terms and conditions of the Creative Commons Attribution-ShareAlike 4.0 International (CC BY-SA 4.0) license (https://creativecommons.org/licenses/by-sa/4.0/). 